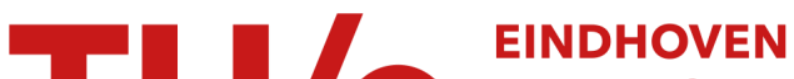 UNIVERSITY OF TECHNOLOGY
}

\section{Hot biogas conditioning using pulsed corona}

\author{
Citation for published version (APA): \\ Heesch, van, E. J. M., Zacharias, P., Paasen, van, S. V. B., Ptasinski, K. J., \& Laan, van der, P. C. T. (1998). \\ Hot biogas conditioning using pulsed corona. In Proc. 23rd International Power Modulator Symposium, Rancho \\ Mirage, CA, 22-25 June 1998 (pp. 24-27). Institute of Electrical and Electronics Engineers. \\ https://doi.org/10.1109/MODSYM.1998.741183, https://doi.org/10.1109/MODSYM.1998.741183
}

DOI:

10.1109/MODSYM.1998.741183

http://dx.doi.org/10.1109/MODSYM.1998.741183

\section{Document status and date:}

Published: 01/01/1998

\section{Document Version:}

Publisher's PDF, also known as Version of Record (includes final page, issue and volume numbers)

\section{Please check the document version of this publication:}

- A submitted manuscript is the version of the article upon submission and before peer-review. There can be important differences between the submitted version and the official published version of record. People interested in the research are advised to contact the author for the final version of the publication, or visit the $\mathrm{DOI}$ to the publisher's website.

- The final author version and the galley proof are versions of the publication after peer review.

- The final published version features the final layout of the paper including the volume, issue and page numbers.

Link to publication

\section{General rights}

Copyright and moral rights for the publications made accessible in the public portal are retained by the authors and/or other copyright owners and it is a condition of accessing publications that users recognise and abide by the legal requirements associated with these rights.

- Users may download and print one copy of any publication from the public portal for the purpose of private study or research.

- You may not further distribute the material or use it for any profit-making activity or commercial gain

- You may freely distribute the URL identifying the publication in the public portal.

If the publication is distributed under the terms of Article 25fa of the Dutch Copyright Act, indicated by the "Taverne" license above, please follow below link for the End User Agreement:

www.tue.nl/taverne

Take down policy

If you believe that this document breaches copyright please contact us at:

openaccess@tue.nl

providing details and we will investigate your claim. 


\title{
HOT BIOGAS CONDITIONING USING PULSED CORONA
}

\author{
E.J.M. van Heesch, High-Voltage \& EMC Group, EUT \\ P. Zacharias, ISET, Institute for Solar Energy Development, Kassel \\ S.V.B van Paasen, Process and Product Design, K.J. Ptasinski, Process Technology Group, EUT \\ P.C.T. van der Laan, High-Voltage \& EMC Group, EUT \\ Mailing address: Eindhoven University of Technology, EUT, div.EVT, P.O.Box 513, 5600MB \\ Eindhoven, The Netherlands, Fax: +31 40245 0735, email: e.j.m.vanheesch@ele.tue.nl
}

\begin{abstract}
A new technology area for pulsed corona is hot biogas cleaning, important in view of the growing interest in biomass gasification. Our work concentrates on the development and optimization of pulsed electrical methods for treatment of thermally generated biogas. Corona energized by narrow voltage pulses $(100 \mathrm{kV})$ makes a well ordered and concentrated deposition possible of electrical energy from a circuit into a hot polluted gas. The created plasmas can break down various contaminants. Successful introduction of pulsed corona for industrial processes very much depends on the reliability of high-voltage and pulsed power technology and on the efficiency of energy transfer. In addition, we must achieve adequate electromagnetic compatibility (EMC).
\end{abstract}

\section{INTRODUCTION}

Basically nearly any type of biogas production has to be followed by gas conditioning systems. Pulsed corona seems to be the only efficient and most simple technology that is perfectly matched for high temperature conditioning of gases. We showed that pulsed corona runs excellently at temperatures of $800^{\circ} \mathrm{C}$ and higher, even under polluted conditions. Corona energized by 50-200 ns wide voltage pulses $(100 \mathrm{kV})$ creates a rather homogeneous time-concentrated deposition of electrical energy into a hot polluted gas. Within a wide range of conditions this creates plasmas that can break down contaminants such as styrene, toluene, ethylene and pentane. A range of questions has to be answered when dealing with pulsed electrotechnology applications for hot gas cleaning. What is the optimal reactor type, pulse type and pulse source, how can we manage the interaction between electrical circuit and discharges?

For conventional technology cleaning of the generated gas is a considerable problem in all cases of thermal gasification of solid biomass.

An intensive cleaning effect was found at low temperatures $[1,6,8]$ : our experiments add to findings in literature $[9,10]$ by showing that organic compounds are easily decomposed by corona discharges. For several hydrocarbons we measured a high removal efficiency at acceptable levels of input energy. Well controlled energy transfer from source to corona was found to be possible for hot exhaust gas [2].

To examine the discharges in the reactor we used current and voltage sensors and a fast CCD camera [1]. Detailed energy input measurements were compared with $\mathrm{CCD}$ movies to investigate the efficiency of different streamer phases.

The pulse parameters often are dictated by gas breakdown more than by plasma chemical processes. Energy transfer from the highvoltage circuit to the gas needs optimization. 
With respect to development of pulsed power for industrial processes we also concentrate on reliability issues and on EMC aspects.

Different types of technologies are considered: from heavy-duty spark gap technology, magnetic compression and transmission line transformers to solid state switches.

The applied EMC techniques rely on methods that consider common mode currents as the major source of possible interference $[3,4]$. Current paths and transfer impedances are to be carefully chosen.

\section{CONTINUOUS MODE PULSE SOURCE}

During the past two years we developed and applied a pulsed corona unit $(1.5 \mathrm{~kW}$ net average corona power) that produces narrow $50 \mathrm{MW}$ pulses $(200 \mathrm{~ns}, 100 \mathrm{kV})$ at $1000 \mathrm{pps}$ [8]. The unit can run continuously for use in industrial applications.

The overall efficiency of energy transfer from mains AC to corona energy is $40-70 \%$. With the unit running 8 hours per day, the time since the last significant failure is passing the 300 hours mark at the moment; we expect to reach 1000 hours by the end of this year. Patent rights have been obtained.

The corona reactor is placed on top of a main EMC casing that encloses the pulse source. For the production of the pulse we use three stages: two subsequent resonant circuits (thyristor switched) coupled by a pulse transformer to pulse charge a $30 \mathrm{kV}$ storage capacitor. A special spark gap discharges this capacitor into a third stage, the transmission line transformer (TLT) [5]. Each stage compresses the pulse duration, and raises the pulse amplitude.

The reliability of the main high-voltage switch, the spark gap, is excellent, after $10^{9}$ pulses $(200 \mathrm{kC})$ only minor electrode wear is visible.
The TLT is a parallel-series connection of 4 coaxial cables, each $12 \mathrm{~m}$ long. Loaded by corona the output voltage is $100 \mathrm{kV}$. The gas to be cleaned flows through a $3.5 \mathrm{~m}$ long stainless steel tube reactor, inner diameter $250 \mathrm{~mm}$. The inside wall is fitted with needles to increase the corona activity. The center electrode is a 3 meter long wire, diameter 1.0 $\mathrm{mm}$.

Increasing the reliability of the unit we encountered the following main problems:

1. major jitter in the time to breakdown of the self-breakdown main spark gap.

2. breakdown in the dielectricum of the TLT.

3. simultaneous opening of all thyristors due to overheating and interference pick-up

Problem 1 was initially solved by adding a recessed trigger electrode that was energized by the swinging-back voltage of the pulse transformer. A further improvement is sought in adding a separate trigger source.

The problems with the TLT were finally solved when we used a heavier type of coaxial cable. The thyristors became reliable after we added EMC improvements and forced air cooling. The operations are going on at the moment and apart from unimportant problems the unit is running day by day and increasing its run hours continuously.

\section{BIOGAS CONDITIONING}

Advantages of pulsed electrical process technology are: capability to simultaneously attack a range of pollutants, excellent energy efficiency, heat conservation of the thermally generated biogas, harmless rest products such as $\mathrm{CO}_{2}, \mathrm{H}_{2} \mathrm{O}$ and $\mathrm{N}$-fertilizers, acceptance of overloads. Common conventional techniques are far from offering these advantages.

A promising kind of renewable energy is the thermal generation of biogas for heat and 


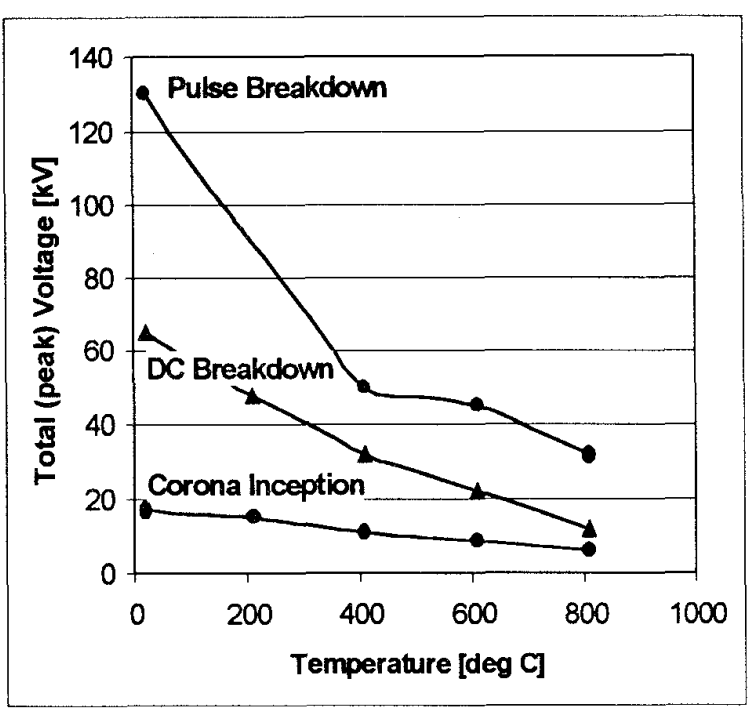

Fig. 1 Corona at temperatures up to $810^{\circ} \mathrm{C}$

power production. Biomass as a clean renewable resource is suitable to secure (local) energy supply and also has the environmental benefits of wood farming $\left(\mathrm{CO}_{2}\right.$ recycling) and the possible use of residues from forestry and agriculture. To supply combustion engines or gas turbines it is necessary to clean the biogas. Various contaminants are detrimental to machine components and will strongly affect maintenance costs. The proposed and investigated pulsed corona method would avoid wet scrubbers, mechanical filters or catalysts. It can operate at the high temperature of a gasifier $\left(900^{\circ} \mathrm{C}\right)$, see Fig. 1 and it is adaptable to varying compositions of input gases and various sizes of biogas plants. It needs no gas conditioning.

Thermally generated biogas contains the main components carbon monoxide (CO) and hydrogen $\left(\mathrm{H}_{2}\right)$ with small portions of methane $\left(\mathrm{CH}_{4}\right)$.

Our work aims at a specific corona treatment method that leaves $\mathrm{CO}, \mathrm{H}_{2}$ and $\mathrm{CH}_{4}$ unaffected. We found that that pulsed corona decomposition of e.g. $\mathrm{CH}_{4}$ is very ineffective: more than $2000 \mathrm{kWh}$ is needed per $\mathrm{kg}$ removed. Removal expressed in terms of specific activation energy (see next section) is shown in table 1.

\begin{tabular}{|l|l|l|}
\hline component & $\begin{array}{l}\text { concentration } \\
{[\mathrm{ppm}]}\end{array}$ & $\begin{array}{l}\text { specific } \\
\text { energy }[\mathrm{J} / \mathrm{l}]\end{array}$ \\
\hline toluene & $125-450$ & 99 \\
\hline styrene & $30-190$ & 11 \\
\hline TCA & $80-1000$ & 135 \\
\hline pentane & $80-1000$ & 185 \\
\hline methane & & $\approx 1000$ \\
\hline
\end{tabular}

Table 1. Specific energies for corona decomposition in mixtures with air.

From our investigations it is known that for a number of hydrocarbons an intensive cleaning effect can be obtained at small amounts of input energy. The power to drive the corona discharges is more than compensated by the gained economy of a gasifier.

\section{REACTOR MODEL}

Pulsed corona creates atmospheric plasmas that generate free radicals, excited molecules and UV radiation. Direct bond cleavage or interaction through radicals decomposes volatile or gaseous pollutants.

An exponential behavior for the hydrocarbon removal $R$ ( $R=C_{\text {out }} / C_{\text {in }}, C$ is concentration) by the pulsed corona reactor was found experimentally and was given as [7]:

$$
R=\exp (-E / \Delta E)
$$

Here $\mathrm{E}$ is the applied corona energy per unit volume and we found [6] that $\Delta \mathrm{E}$ is the specific activation energy per unit volume of the mixture hydrocarbon plus air. Within the concentration ranges of up to $1000 \mathrm{ppm}$ this activation energy for the mixture is independent of the hydrocarbon concentration. The specific activation energy per $\mathrm{m}^{3}$ only varies with the concentration of the mixture: 


$$
\Delta \mathrm{E}=\Delta \mathrm{E}_{0} \mathrm{C}_{\text {mix }} / \mathrm{C}_{\text {mix } 0}
$$

Here $\mathrm{C}_{\text {mix }}$ is number of moles of mixture per unit volume $\left[\mathrm{mol} / \mathrm{m}^{3}\right]$ and $\mathrm{C}_{\text {mixo }}$ and $\Delta \mathrm{E}_{0}$ are the values at STP conditions.

The exponential relationship is very useful for scaling purposes. Some removal processes however do not fit the model.

Our former method to express the efficiency of the removal process gave numbers for hydrocarbons such as: $7 \mathrm{kWh}$ per $\mathrm{kg}$ load for styrene, $24 \mathrm{kWh} / \mathrm{kg}$ load for toluene and 88 $\mathrm{kWh} / \mathrm{kg}$ for $1,1,1$ TCA. Now we will use the newer exponential relation above. It gives fitted values of $11 \mathrm{~J} / 1$ of the mixture for full decomposition of styrene and $99 \mathrm{~J} / 1$ of mixture for a much more stable VOC such as toluene.

To make an estimate for the energy demand of a corona purifier for a thermal biogas installation we could start with a very approximate value of e.g. $15 \mathrm{~J} / \mathrm{l}$ of biogas (at STP) for decomposition of hydrocarbons. The exponential relation above can be used for further evaluation since the undesired hydrocarbons have concentrations in the range to which the method is restricted. To remove $90 \%$ we thus need almost $35 \mathrm{~J} / 1$ at STP. Corrected for the pulse source efficiency this cost still is only a fraction of the actual heating power of biogas.

\section{Acknowledgement}

Research was funded by The Netherlands Technology foundation STW.

\section{REFERENCES}

[1] P.P.M. Blom, "High Power Pulsed Corona", Ph.D. thesis, Eindhoven University of Technology, February 1997

[2] E.J.M. van Heesch, A.J.M. Pemen, P.C.T. van der Laan, "Pulsed Corona Existence up to $850^{\circ} \mathrm{C}$ “, Proc. 6th Int. Symp. on High-
Voltage Eng., New Orleans, 42.23, 1989

[3] M.A. van Houten, "Electromagnetic Compatibility in High-Voltage Engineering", Ph.D. thesis, Eindhoven University of Technology, October 1990

[4] P.C.T. van der Laan, A.P.J. van Deursen, "Linear EMC-Methods applied to Power Systems", Proc. 10th Int. Symp. on HighVoltage Eng., Montreal, 1, p. 59, 1997

[5] I.A.D. Lewis and F.H. Wells, "Millimicrosecond Pulse Techniques", 2nd Ed., Pergamon Press, London, 1959, pp. 109-111.

[6] S.V.B. van Paasen, et al., "Decomposition of VOCs in a Continuous High-Voltage Pulsed Corona Process", Proc. 10th Int. Symp. on High-Voltage Eng., Montreal, 6, p.365, 1997.

[7] L.A. Rosocha, et al., "Treatment of Hazardous Organic Wastes Using Silent Discharge Plasmas", Nonthermal Plasma Techniques for Pollution Control, B, SpringerVerlag, Berlin Heidelberg, 1993, p.281.

[8] H.W.M. Smulders, et al., "Efficiency and Reliability of a Repetitive Pulse Source for Continuous Pulsed Corona Processes", Proc. 10th Int. Symp. on High-Voltage Eng., Montreal, 6, p. 393, 1997

[9] R.A. Roush, et al., "Effects of Pulse Risetime and Pulse Width on the Destruction of Toluene and NOx in a coaxial Pulsed Corona Reactor", Conf. Rec. of the 22nd Int. Power Modulator Symp., p.79, IEEE, 1996.

[10] J.J. Coogan, et al., "Barrier Discharge Treatment of VOC's in Oxygen Lean Mixtures", AOTs-2 Conference, London, Canada, 1995. 